\title{
THE TRANSITION OF ADOLESCENTS TO ADULT NEPHROLOGY CARE: A SURVEY ON YOUNG ADULTS' EXPERIENCE
}

\author{
ADOLESAN HASTALARIN ERIŞKIN NEFROLOJI BÖLÜMÜNE DEVREDILMESI: GENÇ \\ YETIŞKINLERIN DENEYIMLERI
}

\author{
Neslihan ÇiÇEK ${ }^{1}$ iD, Harika ALPAY (D) \\ 'Marmara University, Faculty of Medicine, Department of Pediatrics, Division of Pediatric Nephrology, Istanbul, Turkey
}

ORCID IDs of the authors: N.Ç. 0000-0002-5859-4177; H.A. 0000-0002-0850-1964

Cite this article as: Cicek N, Alpay H. The transition of adolescents to adult nephrology care: a survey on young adults' experience. J Ist Faculty Med 2022;85(1):86-90. doi: 10.26650/IUITFD.910335

\begin{abstract}
Objective: As increasing number of young people with renal diseases are reaching adulthood and issues related to their transition to adult units are getting more important. Failure to transfer adolescents under a well-designed transfer program can lead to a decline in attendance to an adult unit. We aim to share our experience and the views of the patients who went through a transition program.
\end{abstract}

Materials and Methods: We conducted a telephone questionnaire with 88 patients, who were asked to evaluate their concerns before their transition and their experience during the visit in the adult nephrology unit after the transition process.

Results: The mean age of participants was $19.21 \pm 0.97$ years. Thirty patients (34\%) had chronic kidney disease, and three of them were on dialysis. Three patients (3.4\%) had a renal transplant at the time of transition. Fifty-one patients (58\%) were felt anxious before the transition process. After their transfer to the adult unit, although 84 patients (95.5\%) were satisfied to be in the adult unit, there were still 65 patients $(74 \%)$ ready to return to the pediatric unit, if it was possible.

Conclusion: Transition to the adult unit is still a cause of concern for adolescent patients, even if they are transferred under a well-designed program. It is important to raise awareness about transition programs among pediatricians and to develop a pediatric-adult transition program for the medical and psychological well-being of patients.

Keywords: Adolescence, pediatrics, questionnaire, transition

\section{ÖZET}

Amaç: Böbrek hastalığı olan daha fazla sayıda genç hastanın erişkin dönemine ulaşmasıyla, bu hastaların erişkin bölümlerine devredilmesi de giderek önem kazanmaktadır. lyi planlanmış bir program ile devredilmeyen hastalarda erişkin bölümüne uyumda azalma görülebilir. Bu çalışmada devir programı ile erişkin bölümüne geçen hastaların tecrübe ve fikirlerini paylaşmayı hedefledik.

Gereç ve Yöntem: Seksen sekiz hastaya devir öncesi endişelerini ve devir süreci sonrasında erişkin nefroloji ünitesine ziyaret deneyimlerini değerlendiren bir telefon anketi uyguladık.

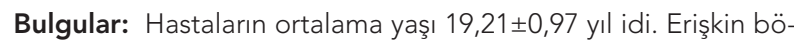
lümüne devir sırasında, otuz hasta (\%34) kronik böbrek hastalığı ile izlenmekteydi, bu hastaların üçü $(\% 3,4)$ diyaliz tedavisi alırken, üçü $(\% 3,4)$ böbrek nakilliydi. Elli bir hasta $(\% 58)$ devir öncesi endişeli olduğunu belirtti. Erişkin bölümüne ziyaretleri sonrasında, 84 hasta $(\% 95,5)$ erişkin bölümündeki takipten memnun olduğunu belirtmesine rağmen, 65 hasta (\%74) mümkün olsa yine de çocuk bölümüne geri dönmek istediklerini belirtti.

Sonuç: İyi tasarlanmış bir programla erişkin bölümüne geçmiş olsalar bile, devir adolesan hastalar için hala bir endişe kaynağıdır. Çocuk doktorları arasında devir programları hakkında farkındalık yaratmak ve hastaların tıbbi ve psikolojik iyiliği için bir pediyatrik-yetişkin devir programı geliştirmek önemlidir.

Anahtar Kelimeler: Adolesan, pediatri, anket, devir

Corresponding author/iletişim kurulacak yazar: drneslihancicek@yahoo.com

Submitted/Başvuru: 17.03.2021 • Revision Requested/Revizyon Talebi: 15.04.2021 • Last Revision Received/Son Revizyon: 16.04.2021 • Accepted/Kabul: 28.04.2021 • Published Online/Online Yayın: 29.11.2021 


\section{INTRODUCTION}

More children with chronic diseases survive into adulthood with improvements in medicine, therefore the transition of adolescents into adult units is becoming an increasingly important issue (1-3). Because of the emotional, social and psychological changes during adolescence, health problems may become more apparent (4). Moreover, the expectations of adult units are more than the pediatric units in terms of taking the responsibility of their illness (2).

Medical transition is a planned movement of adolescents with chronic medical conditions from child-centered to adult-orientated healthcare units. The aim of a transition process is to ensure the continuity of lifelong functioning and well-being for young patients, who have special health care needs and those who do not. A timely and well-designed transition process should be specific to each patient and the timing is most appropriate between the ages of 18 and 21 years. The participants of a transition process are pediatricians, nurses, adult healthcare providers, patients and families (5). The coordination between the patient, family and the health care provider is important for the adolescent in order to assume responsibilities of adult roles and activities (6). When transferred without a transition process, poor health outcomes have been reported such as worsening of glycemic control in patients with diabetes mellitus, seizure control in those with epilepsy and graft failure in transplant recipients. Poor health outcomes were also reported in patients with pediatric cancers and cardiac surgery (7-9).

An appropriate and successful transition is very important in terms of future treatment and the compliance of patients with chronic illness.

We aim to share our experiences and views of the patients who went through a transition program.

\section{MATERIALS AND METHODS}

The transition process was achieved in a transition outpatient clinic with the participation of the patient, family, nurses, pediatric nephrologist and adult nephrologist. The study was conducted in accordance with the requirements of the Helsinki Declaration and was approved by the local Ethical Committee (Date: 02.10.2020 No: 1045). The recorded past medical history of the patients was summarized by a pediatric nephrologist and the medical records were reviewed and discussed by two nephrologists. The adult nephrologist, the patient and the family were introduced to each other. At the end of the interview, an appointment was scheduled for the patient in the adult nephrology unit.

We developed a telephone questionnaire of five questions evaluating the patients' concerns before transition and their experience about the visit to the adult nephrology unit after the transition process. We conducted the questionnaire for the patients who had at least one visit to the adult unit (Table 1).

Table 1: Questions in the interview

\section{Questions}

1 Were you anxious about your transition to adult unit?

2 If it is avaiable, do you want to return to pediatric unit again?

3 Do you think the knowledge given about your illness was satisfactory?

4 Did you need to take a second opinion after transition?

5 Are you happy about adult unit follow up?

\section{RESULTS}

A total of 88 patients ( 44 male, 44 female) completed the questionnaire. The mean age of participants was 19.21 \pm 0.97 years (range: 18-22). Thirty patients (34\%)

Table 2: Diagnosis of patients

\begin{tabular}{lccc}
\hline Diagnosis & Patients with CKD $(\mathbf{n}=\mathbf{3 0})$ & Patients with renal tx $(\mathbf{n}=\mathbf{3})$ & Other patients $(\mathrm{n}=\mathbf{5 5})$ \\
Uropathy & 17 & 2 & 8 \\
Primary glomerulopathies & 3 & 1 & 25 \\
Hypertension & & & 8 \\
Orthostatic proteinuria & 6 & 3 \\
SB + NB & 1 & 3 \\
Nephrolithiasis & & 3 \\
FMF & & 2 \\
DM + proteinuria & & 2 \\
Cystic disease & 3 & 1 \\
Unknown & & & 3 \\
\hline
\end{tabular}

CKD: Chronic kidney disease, tx: transplantation, SB: Spina bifida, NB: Neurogenic bladder, FMF: Familial mediterranean fever, DM: Diabetes mellitus 
were diagnosed with chronic kidney disease (CKD), and three of them were on dialysis. Three patients (3.4\%) had a renal transplant from deceased donors at the time of transition. The diagnoses of the patients are shown in Table 2. Two patients with end stage renal disease (ESRD) had renal transplantation from living donors, within six months after being transferred to the adult clinic. When we evaluated the answers of the patients;

1. Fifty-one patients (58\%) were anxious about the transition to the adult unit before the process. Their major concern was leaving the pediatric unit where they were known well.

2. Although most of them were satisfied, $74 \%$ of patients were ready to return to the pediatric unit, if possible.

3. $92 \%$ of patients were satisfied with the knowledge and answers given to him/her.

4. $84 \%$ of patients were not keen on consulting another doctor about their illness.

5. $95 \%$ of patients were satisfied with being followed-up under the adult unit (Table 3).

Table 3: Answers of the patients transferred to adult unit

\begin{tabular}{lcc}
\hline $\mathbf{8 8}$ patients & Yes & No \\
(44 male, 44 female) & $\mathbf{n}(\%)$ & $\mathbf{n}(\%)$ \\
Concerned about transition & $51(58)$ & $37(42)$ \\
$\begin{array}{l}\text { Return to pediatric unit again } \\
\text { Satisfactory knowledge about }\end{array}$ & $65(74)$ & $23(26)$ \\
your illness & & $7(8)$ \\
$\begin{array}{l}\text { Need a second opinion about } \\
\text { your illness }\end{array}$ & $14(16)$ & $74(84)$ \\
Pleased about adult unit follow up & $84(95.5)$ & $4(4.5)$ \\
\hline
\end{tabular}

Sixteen patients (18.2\%), all with CKD, were older than 20 years of age at the time of transition and all of them were categorised into the anxious group based on their answers to question 1. However, they were all satisfied to be followed by the adult unit after the transition process.

\section{DISCUSSION}

As increasing number of young people with chronic illnesses are reaching adulthood and issues related to their transition to adult units are getting more important.

The American Academy of Pediatrics, The American Academy of Family Physicians, and American College of Physicians published a clinical report supporting the health care transition from adolescence to adulthood. The aim of the report was to ensure the continuity of lifelong functioning and well-being for young patients (6).

The studies showed that transfer of patients to adult clinics without a transition process has an adverse effect on their follow-up. O'Leary C et al. showed that only $22 \%$ of patients with celiac disease in childhood were admitted to an adult gastroenterology clinic and most of the patients received no medical or dietary supervision after leaving pediatric units (1). It is also reported that transition programs provide better $\mathrm{HbAlc}$ levels and health outcomes in patients with diabetes mellitus (7). In case of a poorly organized transition, suboptimal seizure control and an increased risk of sudden unexpected death were reported in patients with epilepsy (9).

With the advances in dialysis and renal transplantation, the prognosis of children with ESRD improved dramatically and most of them survive into adulthood (10). Adolescents constitute approximately $3 \%$ of the ESRD population. Non-adherence to diet, medical treatment and missed dialysis sessions are more common among these patients. In childhood, including infancy, the prognosis of the disease is the worst during the adolescence period. An inappropriate transition to adult clinic in patients with CKD and ESRD has been shown to adversely affect quality of life and prognosis $(11,12)$.

In a study evaluating renal transplant patients, the decline in estimated glomerular filtration rate (eGFR) was significantly lower in the transition group compared to the non-transition group after three years (-11.3 vs -28.4$)$. The rate of rejections was $34.6 \%$ in the non-transition group and $9.1 \%$ in the transition group. The results support positive effects of the transition process on eGFR and rate of acute rejections in renal transplant patients (13).

Some of the patients continue to be under pediatric follow-up longer than is actually required because of their concerns about leaving the pediatric unit. However, pediatricians are not experienced in adult-related issues such as contraception, pregnancy and employment (2). Tuffrey et al. have reported the following barriers in the transition process: The pediatric team is reluctant to transfer their patients as they consider adult units to be inferior, furthermore the adult health care providers have no experience of pediatric conditions and the families have concerns about the adult units and a loss of control (14). We were also reluctant to transfer our patients with diagnoses which adult nephrology team is not experienced such as cystinuria, hyperoxaluria and the patients who had CKD and a long follow-up time in pediatric unit.

Adolescents indicated that age should not be the only criteria for the timing of transfers and they wanted to be involved in the decision-making process for the transfer (15). For pediatric patients and their families, one of the most important periods in their lives is the time of the transition to adult units. The patients should be informed about the transition process, beginning from early adolescence (12-14 years) and the information about the 
transition should be appropriate to his/her developmental stage (10). In a study evaluating 21 adolescents' views about the transition process from the patient's perspective, the patients emphasized that building new relationships with adult care doctors and adjusting to the adult model of care took a while and they missed the relationship with the pediatric doctors who knew them well (16).

We investigated the views of pediatric patients with renal disease who were transferred to the adult nephrology unit. The patients were informed about their transition, starting between the ages of 14-16 years and they were transferred to the adult unit between 18-22 years of age.

Although the sample size was small, interviews with 88 young adults allowed us to learn their concerns with regards to their transition process and their views after their visit to the adult unit. The survey results showed that more than half of the patients were anxious about the process before transition to the adult unit and their major concern was leaving the pediatric unit who knew them well. All the patients, who were older than 20 years and had CKD, were anxious and unwilling to leave the pediatric unit. It can be speculated that patients with chronic conditions and a long duration of follow-up in the pediatric unit have much tighter bonds with the pediatric team and greater difficulties during transition. Although they were anxious before the transition, all of them were satisfied to be under the follow-up of the adult unit after the transition process, which shows their adaptation.

After their visit to the adult unit, most of the patients were satisfied with being followed-up by the adult clinic; nevertheless $74 \%$ of the patients were still eager to return to the pediatric unit, which shows the strong relationship established between the patients and the pediatric team.

While the pediatricians are willing to speak more about the illness, the clinical presentation and the social events with the child and also the family, most of the adult doctors focus on the illness and the clinic of the adult patient and speak only with the patient. We also observed the same in our survey and found out that our patients were ready to be treated as an adult.

In a review of several transition studies, patient education and transition through a specific transition clinic were the most successful strategies in transition processes (7). Achieving a successful transition is possible by using a transition clinic, where the patient is seen both by pediatric and adult specialists together (10). We couldn't provide a separate transition clinic but we transferred our patients in an outpatient clinic, dedicated only to the transition process.

In conclusion, we showed that most of our patients were anxious about the process before their transition to the adult unit. After a successful transition program, they were ready to be treated as an adult patient and satisfied to be in the adult unit, however, most of the patients were still missing us.

It is important to raise awareness about transition programs among pediatricians and to develop a pediatric-adult transition program for the medical and psychological well-being of patients.

Ethics Committee Approval: This study was approved by the Clinical Research Ethical Committee of Marmara University (Date: 02.10.2020 No: 1045).

Peer Review: Externally peer-reviewed.

Author Contributions: Conception/Design of Study- N.Ç., H.A.; Data Acquisition- N.Ç.; Data Analysis/Interpretation- N.Ç., H.A.; Drafting Manuscript- N.Ç.; Critical Revision of Manuscript- H.A.; Approval and Accountability- N.Ç., H.A.

Conflict of Interest: Authors declared no conflict of interest.

Financial Disclosure: Authors declared no financial support.

\section{REFERENCES}

1. O'Leary C, Wieneke P, Healy M, Cronin C, O'Regan $\mathrm{P}$, Shanahan F. Celiac disease and the transition from childhood to adulthood: a 28-year follow-up. Am J Gastroenterol 2004;99(12):2437-41. [CrossRef]

2. Khan A, Baheerathan A, Hussain N, Whitehouse W. Transition of children with epilepsies to adult care. Acta Paediatr 2013;102(3):216-21. [CrossRef]

3. Srivastava SA, Elkin SL, Bilton D. The transition of adolescents with chronic respiratory illness to adult care. Paediatr Respir Rev 2012;13(4):230-5. [CrossRef]

4. Alpay $\mathrm{H}$. Transition of the adolescent patient to the adult clinic. Perit Dial Int 2009;29(Suppl 2):180-2. [CrossRef]

5. Ishizaki $Y$, Maru M, Higashino H, Katsumoto S, Egawa $K$, Yanagimoto $Y$, Nagahama T. The transition of adult patients with childhood-onset chronic diseases from pediatric to adult healthcare systems: a survey of the perceptions of Japanese pediatricians and child health nurses. Biopsychosoc Med 2012;6:8. [CrossRef]

6. Cooley WC, Sagerman PJ. Supporting the health care transition from adolescence to adulthood in the medical home. Pediatrics 2011;128(1):182-200. [CrossRef]

7. Crowley R, Wolfe I, Lock K, McKee M. Improving the transition between paediatric and adult healthcare: a systematic review. Arch Dis Child 2011;96(6):548-53. [CrossRef]

8. Watson AR. Non-compliance and transfer from paediatric to adult transplant unit. Pediatr Nephrol 2000;14(6):469-72. [CrossRef]

9. Camfield PR, Andrade D, Camfield CS, Carrizosa-Moog J, Appleton R, Baulac M, et al. How can transition to adult care be best orchestrated for adolescents with epilepsy? Epilepsy Behav 2019;93:138-47. [CrossRef] 
10. Watson AR, Harden P, Ferris M, Kerr PG, Mahan J, Ramzy MF. Transition from pediatric to adult renal services: a consensus statement by the International Society of Nephrology (ISN) and the International Pediatric Nephrology Association (IPNA). Pediatr Nephrol 2011;26(10):1753-7. [CrossRef]

11. Ferris ME, Cuttance JR, Javalkar K, Cohen SE, Phillips A, Bickford $K$, et al. Self-management and transition among adolescents/young adults with chronic or end-stage kidney disease. Blood Purif 2015;39(1-3):99-104. [CrossRef]

12. Bell L. Adolescent dialysis patient transition to adult care: a cross-sectional survey. Pediatr Nephrol 2007;22(5):720-6. [CrossRef]

13. Weitz M, Heeringa S, Neuhaus TJ, Fehr T, Laube GF. Standardized multilevel transition program: Does it affect renal transplant outcome? Pediatr Transplant 2015;19(7):691-7. [CrossRef]
14. Tuffrey C, Pearce A. Transition from paediatric to adult medical services for young people with chronic neurological problems. J Neurol Neurosurg Psychiatry 2003;74(8):1011-3. [CrossRef]

15. Tong A, Wong G, Hodson E, Walker RG, Tjaden L, Craig JC. Adolescent views on transition in diabetes and nephrology. Eur J Pediatr 2013;172(3):293-304. [CrossRef]

16. Catena G, Rempel GR, Kovacs AH, Rankin KN, Muhll IV, Mackie AS. "Not such a kid thing anymore": Young adults' perspectives on transfer from paediatric to adult cardiology care. Child Care Health Dev 2018;44(4):592-8. [CrossRef] 